\title{
Access To Justice of Citizenship Rights for Stateless Indonesian Migrant Workers' Children In Sarawak, Malaysia
}

\author{
Yayan Sopyan \\ Universitas Islam Negeri Syarif Hidayatullah, Jakarta \\ Jl. Ir. H. Djuanda No. 95, Ciputat, Tangerang Selatan \\ Email:yayan_sopyan@uinjkt.ac.id
}

Article history: Received: September 28, 2020, Accepted: December 21, 2021,

Published: December 27, 2021

\begin{abstract}
:
As one of the countries that ratified the United Nations Convention on the Rights of the Child in 1990 which was subsequently promulgated into the Child Protection Act, Indonesia is still unsuccessful in protecting children. This mainly occurs in the context of protection illegal migrant workers' children who were born in the country where their parents work. In Sarawak, Malaysia, for instance, there are 43,445 stateless children. This study aims to portray the stateless children in Sarawak, Malaysia, and the efforts of the Indonesian government to protect their right to access justice. This research is normative-qualitative with observations and in-depth interviews with consultant general staff and Indonesian volunteers In Sarawak as one of the main research methods. The results of this study indicate that stateless condition makes it possible for the children to get other rights, such as education. Meanwhile, the Indonesian government has already made regulations and efforts to provide access to basic human rights for children of stateless migrant workers, including itsbat nikah abroad to legalize unregistered marriage among workers. However, it has not been fully successful because the problems are so complex that it needs to involve several parties, especially the Malaysian government, and plantation owners as employers of the migrant workers.
\end{abstract}

Author correspondence email: yayan_sopyan@uinjkt.ac.id Available online at: http:/ / ejournal.iainmadura.ac.id/index.php/alihkam/ Copyright (c) 2021 by al-ihkam. All Right Reserved 
Likewise, harder and more coordinated efforts are also needed to fulfill their citizenship right.

Keywords:

Stateless children; Migrant workers; Malaysia; Access to Justice

\begin{abstract}
:
Sebagai salah satu negara yang meratifikasi Konvensi PBB tentang Hak Anak pada 1990 dan kemudian dikristalkan menjadi Undang-undang Perlidungan Anak, Indonesia ternyata belum sepenuhnya berhasil melindungi hak-hak anak. Ini utamanya berlaku dalam konteks perlindungan terhadap anak para buruh migran yang lahir dan tinggal di negara tempat orang tuanya bekerja. Di Sarawak, Malaysia, ada 43.445 anak-anak tanpa kewarganegaraan. Penelitian ini bertujuan memotret kondisi anak buruh migran ilegal tanpa kewarganegaraan di Serawak, Malaysia, serta menjelaskan upaya pemerintah Indonesia untuk melindungi hak-hak mereka. Penelitian ini bersifat normatif-kualitatif dengan observasi dan wawancara mendalam kepada pegawai Konsulat Jenderal dan relawan Indonesia sebagai salah satu metode penggalian data utamanya. Hasil dari penelitian ini menunjukkan bahwa status tanpa kewarganegaraan menghalangi anak-anak tersebut mengakses hak-haknya yang lain, semisal pendidikan. Sementara itu, pemerintah Indonesia sudah memiliki beberapa aturan tertulis dan berupaya memberikan akses keadilan bagi anak para buruh migran tersebut, termasuk melalui program itsbat nikah di luar negeri. Namun demikian, situasi belum sepenuhnya terkendali karena permasalahan yang begitu kompleks dan mengharuskan keterlibatan banyak pihak, utamanya pemerintah Malaysia dan para pemilik perkebunan. Perlu juga dilakukan upaya yang lebih keras dan terkordinasi agar hak-hak tersebut dapat terpenuhi.
\end{abstract}

\title{
Keywords:
}

Anak tanpa kewarganegaraan; Buruh migran; Malaysia; Akses pada keadilan 
Yayan Sopyan

\section{Introduction}

Indonesia got involved in the ratification of the United Nations Convention on the Rights of the Child in 1990 which was subsequently followed by Law Number 23 of 2002 concerning Child Protection and was revised into Law No. 35 of 2014. However, it is still not quite successful in protecting children, particularly stateless children of illegal migrant workers in the country where their parents work. Providing legal protection to unlucky children with no citizenship status should be a concern and a top priority for the Indonesian government because it involves the good name and pride of the nation.

Nowadays, tens of thousands of Indonesian children in Sarawak, Malaysia, do not have any citizenship because their parents came to Sarawak as illegal immigrant workers.1 Sarawak is distinctive for various reasons. First, it is quite close and directly adjacent to Indonesia. Second, the number of both illegal migrant workers and stateless children is very large. Fourth, Itsbat (marriage settlement) court services are relatively small compared to other places like Sabah.

In general, Malaysia is a home for Indonesian migrant workers from year to year. The data from BP2MI (Badan Perlindungan Pekerja Migran Indonesia/Indonesian Migrant Workers Protection Agency) in 2020 shows as follow: ${ }^{2}$

1 Sri Wiyanti Eddyono, Research Report: The Profile of Trafficking in Persons in The Border Area of Kalimantan, Studies of The Districts of Sanggau, Sambas, Kapuas Hulu and Nunukan, ed. oleh Counter-Trafficking Unit IOM Indonesia (Jakarta: International Organization for Migration (IOM) Indonesia, 2020), hlm. 23. https://indonesia.iom.int/sites/indonesia/files/publication/The Profile of Trafficking in Persons in The Border Area of Kalimantan.pdf.

2 BP2MI, "Data on Placement and Protection of Indonesian Migrant Workers," Pusat Data dan Informasi, BP2MI, Periode tahun 2020. file:/ / C:/Users/dryay/Downloads/data_27-02-

2021_Laporan_Pengolahan_Data_Th_2020.pdf 
Table 1

The number of Indonesian Migrant Worker In Malaysia.

\begin{tabular}{ccc}
\hline No. & Year & Total \\
\hline 1 & 2017 & 88.991 \\
2 & 2018 & 90.671 \\
3 & 2019 & 79.663 \\
4 & 2020 & 16.542 \\
\hline
\end{tabular}

Source: Data taken from BP2MI, 2020

Some determining factors influence Indonesian migrant workers to choose Malaysia even though an illegal scheme. They are higher income than working in their own country, ${ }^{3}$ strong solidarity among fellow workers, ${ }^{4}$ and information about the success of Malaysian migrant workers through channels of friendship, brotherhood, neighbourhood, and ethnic communities. ${ }^{5}$ Particularly in Sarawak, companies in the plywood industry and oil palm plantation sector are even dependent on Indonesian migrant workers. 95\% of their foreign workers come from Indonesia6 scattered across approximately 135 palm oil companies.7

It has been three generations of illegal migrant workers in Sarawak, Malaysia. The majority come from Sulawesi, East Nusa Tenggara and West Nusa Tenggara.8 Their departure process is

${ }^{3}$ Douglas S. Massey and others, Theories of International Migration: A Review and Appraisal. Population and Development Review, 1993.

${ }^{4}$ Ridwan Wahyudi, 'Illegal Journey: The Indonesian Undocumented Migrant Workers to Malaysia.', Populasi, 25.2 (2017), 24.

${ }^{5}$ Dimas Teguh Prasetyo, Tarma, and Vera Utami Gede Putri, ', Aku Masih Cinta Indonesia : Study of Nationalism in Family Character Education on Children of Indonesian Migrant Workers in Malaysia', Journal of Family Welfare and Education, 7.1 (2020).

6 BNP2TKI, Data on the protection and placement of Indonesian migrant $\quad$ workers. Accessed via site http://www.bnp2tki.go.id/uploads/statistik/images/data_22-042020_Laporan_Pengolahan_Data_BNP2TKI.

${ }^{7}$ Feby Dwi Sutianto, 400.000 WNI Di Sarawak, Legal Atau Ilegal?, 2018.

8https://nasional.kompas.com/read/2020/08/05/ A strong indication that labor entering Malaysia is illegal is the low number of 
facilitated by unscrupulous cukong or tekong (labor brokers) who work with the company and automatically make them low-income as well as illegal labors. They have no official document and sometimes, the brokers cheat on them 9 by robbing their passports 10 so that they can't go home.11 As illegal workers, they are placed in workers' barracks on plantations area which is located remotely in the middle of the forest and are closely guarded by the security forces.12

While working on the plantation, they interact with each other, including between men and women which sometimes leads to the marriage relationship. However, because Malaysian Immigration Act Number 1154A/2002 obliges migrant workers to have legal documents while prohibiting them to bring their families along and get married during the employment contract period, they choose unregistered marriage. The settlement is usually carried out by those who are considered to have sufficient religious understanding.13

Responding to this situation, in the last 2011, the Supreme Court of the Republic of Indonesia initiated a Circuit Court (Sidang Keliling)

migrant worker placements by district/city: except for East Lombok. The highest is Indramayu district, then East Lombok and Kab. Cirebon. From East Nusa Tenggara and South Sulawesi, they are not included in the regencies/cities that send large numbers of workers. See Data on protection and placement of Indonesian migrant workers in year. 2019. page. 10.

9 https://www.antaranews.com/berita/2075754/pekerja-migran-danpraktik-penipuan-yang-menyelimutinya. Baca juga : https://koran.tempo.co/read/berita-utama-jateng/408909/cerita-tipu-tipucalo-buruh-migran.

10 https:// buruhmigran.or.id/2010/06/24/tki-jangan-berikan-pasporanda-kepada-siapapun/.

11 Republik Indonesia, Naskah Akademik RUU Tentang Pengesahan Asean Convention Againts Trafficking in Persons, Especially Women and Children (Konvensi Asean Menentang Perdagangan Orang Terutama Perempuan Dan AnakAnak (Jakarta: Kementerian Hukum dan Hak Asasi Manusia, 2016).

12 Yayan Sopyan, 'The Access to Justice for Indonesian Migrant Workers (In Malaysia, Saudi Arabia and Hongkong)', International Journal of Advanced Science and Technology, 29 No (2020), 95-108.

13 Alfan Faizin, Alfitra, and Ali Mansur, 'Legalizing Unofficial Marriage For Indonesian Migrant Workers In Malaysia', Jurnal Cita Hukum, 7.1 (2020). 
for organizing the marriage settlement (itsbat). It was then followed by Supreme Court Regulation Number 1 of 2015 concerning Integrated Services for Circuit Courts of District Courts and Religious Courts/Sharia Courts in the Context of Issuing Marriage Certificates, Marriage Books, and Deeds of Birth. Particularly related to unregistered marriage, this program targets migrant workers who cannot return to Indonesia in close time to legalize their marriage formally. The only court authorized to organize itsbat abroad is the Central Jakarta Religious Court. However, the itsbat takes place at the Indonesian Embassy in Malaysia or the consul general's office as Indonesia's executorial area. According to international law, it refers to an area under the jurisdiction of a country (Indonesia, in this case) located within the territory of another country (Malaysia). The following table shows the result of the program in the last ten years.

Table 2

Recapitulation Of Acceptance Of Itsbat (The Determination Of Marriage) Trials Abroad At Central Jakarta Religious Courts

\begin{tabular}{|c|c|c|c|c|c|c|c|c|}
\hline $\begin{array}{l}\mathbf{N} \\
\mathbf{0}\end{array}$ & Place and Time & $\begin{array}{l}\text { Appr } \\
\text { oved }\end{array}$ & $\begin{array}{c}\text { Remo } \\
\text { ved }\end{array}$ & $\begin{array}{c}\text { Cancel } \\
\text { ed }\end{array}$ & $\begin{array}{l}\text { Acce } \\
\text { pted }\end{array}$ & $\begin{array}{c}\text { Rejec } \\
\text { ted }\end{array}$ & $\begin{array}{l}\text { Withdrawn } \\
\text { from Register }\end{array}$ & Total \\
\hline 1 & $\begin{array}{l}\text { Consulate General of the } \\
\text { Republic of Indonesia in } \\
\text { Kinabalu, June 18-25, } \\
2011\end{array}$ & 332 & 0 & 29 & 5 & 0 & 0 & 266 \\
\hline 2 & $\begin{array}{l}\text { Consulate General of the } \\
\text { Republic of Indonesia in } \\
\text { Kuching, }\end{array}$ & 101 & 0 & 43 & 0 & 0 & 0 & 144 \\
\hline 3 & $\begin{array}{l}\text { Consulate General of the } \\
\text { Republic of Indonesia in } \\
\text { Kinabalu, December 17- } \\
21,2012\end{array}$ & 147 & 1 & 147 & 0 & 0 & 0 & 295 \\
\hline 4 & $\begin{array}{l}\text { Consulate General of the } \\
\text { Republic of Indonesia in } \\
\text { Tawau, December 17-21, } \\
2012\end{array}$ & 474 & 2 & 18 & 0 & 0 & 0 & 494 \\
\hline 5 & $\begin{array}{l}\text { Consulate General of the } \\
\text { Republic of Indonesia in } \\
\text { Jeddah, October 8-10, } \\
2013\end{array}$ & 67 & 5 & 56 & 0 & 0 & 0 & 128 \\
\hline 6 & $\begin{array}{l}\text { Consulate of the } \\
\text { Republic of Indonesia in } \\
\text { Tawau, December 8-10, }\end{array}$ & 284 & 1 & 37 & 0 & 0 & 0 & 322 \\
\hline
\end{tabular}




\begin{tabular}{|c|c|c|c|c|c|c|c|c|}
\hline $\begin{array}{l}\mathbf{N} \\
\mathbf{o}\end{array}$ & Place and Time & $\begin{array}{l}\text { Appr } \\
\text { oved }\end{array}$ & $\begin{array}{c}\text { Remo } \\
\text { ved }\end{array}$ & $\begin{array}{c}\text { Cancel } \\
\text { ed }\end{array}$ & $\begin{array}{l}\text { Acce } \\
\text { pted }\end{array}$ & $\begin{array}{c}\text { Rejec } \\
\text { ted }\end{array}$ & $\begin{array}{l}\text { Withdrawn } \\
\text { from Register }\end{array}$ & Total \\
\hline & 2014 & & & & & & & \\
\hline 7 & $\begin{array}{l}\text { Consulate of the } \\
\text { Republic of Indonesia in }\end{array}$ & 274 & 5 & 13 & 0 & 0 & 0 & 292 \\
\hline & $\begin{array}{l}\text { Tawau, December 21-23, } \\
2015\end{array}$ & & & & & & & \\
\hline 8 & $\begin{array}{l}\text { Consulate General of the } \\
\text { Republic of Indonesia in } \\
\text { Kuching, September 26- } \\
28,2016\end{array}$ & 106 & 1 & 84 & 0 & 0 & 0 & 191 \\
\hline 9 & $\begin{array}{l}\text { Consulate General of the } \\
\text { Republic of Indonesia in } \\
\text { Jeddah October 3-5, } 2016\end{array}$ & 42 & 44 & 42 & 0 & 0 & 0 & 127 \\
\hline 10 & $\begin{array}{l}\text { Consulate General of the } \\
\text { Republic of Indonesia in } \\
\text { Kinabalu, October 17-19, } \\
2016\end{array}$ & 187 & 2 & 25 & 0 & 0 & 0 & 200 \\
\hline 11 & $\begin{array}{l}\text { Consulate of the } \\
\text { Republic of Indonesia in } \\
\text { Tawau, November 7-10, } \\
2016\end{array}$ & 245 & 6 & 12 & 0 & 0 & 0 & 263 \\
\hline 12 & $\begin{array}{l}\text { Consulate General of the } \\
\text { Republic of Indonesia in } \\
\text { Kinabalu, December 5-7, } \\
2016\end{array}$ & 183 & 2 & 25 & 0 & 0 & 0 & 210 \\
\hline 13 & $\begin{array}{l}\text { Consulate General of the } \\
\text { Republic of Indonesia in } \\
\text { Kuching, May 16-18, } 2017\end{array}$ & 221 & 0 & 33 & 0 & 1 & 0 & 255 \\
\hline 14 & $\begin{array}{l}\text { Consulate General of the } \\
\text { Republic of Indonesia in } \\
\text { Kinabalu, May 22-24, } \\
2017\end{array}$ & 231 & 1 & 18 & 0 & 0 & 0 & 250 \\
\hline 15 & $\begin{array}{l}\text { Consulate General of the } \\
\text { Republic of Indonesia in } \\
\text { Kinabalu, October 9-10, } \\
2017\end{array}$ & 293 & 0 & 8 & 0 & 0 & 0 & 301 \\
\hline 16 & $\begin{array}{l}\text { Consulate of the } \\
\text { Republic of Indonesia in } \\
\text { Tawau, December 4-7, } \\
2017\end{array}$ & 272 & 3 & 20 & 0 & 0 & 0 & 295 \\
\hline 17 & $\begin{array}{l}\text { Consulate General of the } \\
\text { Republic of Indonesia in } \\
\text { Kinabalu, April 2-4, } 2018\end{array}$ & 251 & 0 & 9 & 0 & 0 & 0 & 260 \\
\hline 18 & $\begin{array}{l}\text { Consulate General of the } \\
\text { Republic of Indonesia in }\end{array}$ & 240 & 8 & 12 & 0 & 0 & 0 & 260 \\
\hline
\end{tabular}


Access To Justice of Citizenship Rights

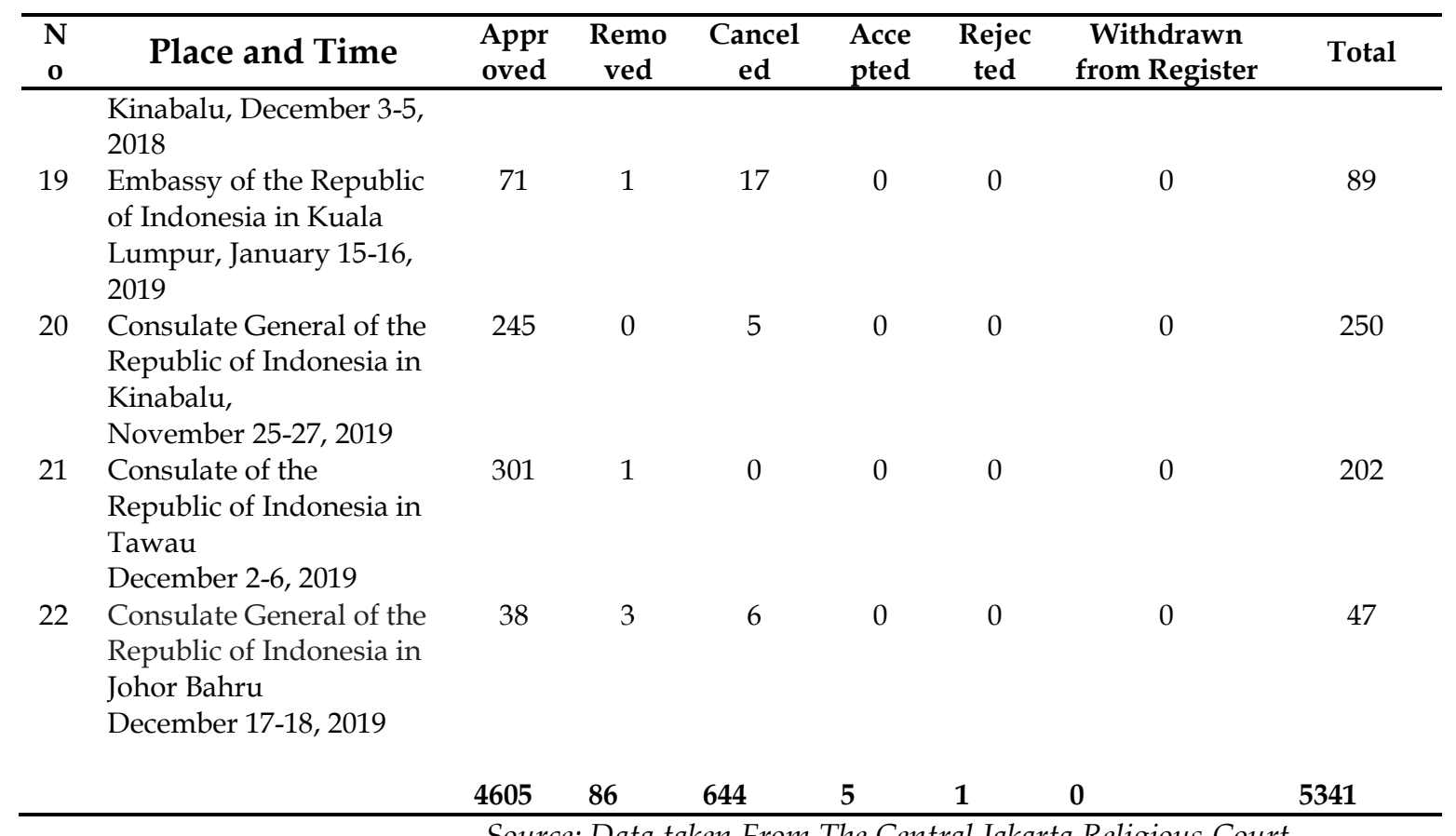

Although the itsbat was not held in the last two years due to the Covid 19 pandemic, the table clearly shows that the total number of itsbat abroad from 2011 to 2019 is quite high numbering 5341. 4,986 cases were in Malaysia with 590 of them from Sarawak. This program mainly aims to facilitate a husband and wife from unregistered marriage to have marriage certificates so that they can further get birth certificates and passports for themselves and their children. However, the program does not solve the problem because the numbers of stateless children, particularly in Sarawak, were increasing year by year. Most of them come from unregistered marriages so that they don't have any legal citizenship identity. ${ }^{14}$ This condition is quite alarming not only because they do not have official citizenship documents, but also access to their basic right, including education. There are at least three reasons why stateless children get difficulty in

${ }^{14}$ Disca Betty Viviansari and Zendy Wulan Ayu Widhi Prameswari, 'State Responsibilities of Rights to Education for Indonesian Migrant Worker's Children in Malaysia', Jurnal HAM, 10.2 (2019), 182. 
accessing education: First, Malaysian Immigration Act Number 1154A/2002 the Malaysian government makes it difficult for children of migrant workers to get education in any public schools. Second, there is a lack of teaching and learning facilities available for stateless children. The number of CLC (Community Learning Center) built by plantation owners and the Indonesian government as a place to study for migrant workers' children is not sufficient. Third, the awareness of migrant workers toward children's education is still low. The three factors lead the children to prefer to help their parents rather than go to school. ${ }^{15}$

The topic of the rights of migrant workers' children to get basic rights in obtaining citizenship status has not been widely discussed. However, some researches have been conducted and the results are close to or almost the same as Benjamin Harkins' reserach. He writes Access to Justice for Migrant Worker in South-East Asia but does not talk about Indonesian migrant workers at all. ${ }^{16}$ Hidayat, meanwhile, wrote an article titling The Protection of Indonesian Workers' Rights in Taiwan and Malaysia in Human Rights Perspective $^{17}$ but did not discuss the issue of migrant workers' children obtaining citizenship status and rights. Another research result from Child Rights International Network Rights, Remedies \& Representation called Global Report on Access to Justice for Children didn't cover children's rights in obtaining citizenship. Accordingly, Catherine Allerton in her article titling Statessness and the Lives of the Children of Migrants in Sabah, East Malaysia,18 explains the fate of Indonesian and Filipino stateless children in Sabah. She found that those children may be recognized by the country of their parents although families often prefer not to have official documents of them and instead expect to become Malaysian citizens.

${ }^{15}$ Benjamin Harkons and Meri Ahlberg, Access to Justice for Migrant Worker Ins South-East Asia (Bangkok: ILO, 2017).

${ }^{16}$ Hidayat, 'Protection of Indonesian Workers Rights in Taiwan And Malaysia in Human Rights Perspective', Jurnal HAM, 8.2 (2017), 106.

${ }^{17}$ Hidayat, 'Protection of Indonesian Workers Rights in Taiwan And.

${ }_{18}$ Cetherine Allerton, 'Statelessness and the Lives of the Children of Migrants in Sabah, East Malaysia.', Tilburg Law Review: Journal of International and European Law, 19.1-2 (2014), 26-34. 
Filling the gap of those previous researches, this research aims to portray how Indonesian illegal migrant workers' stateless children in Sarawak have citizenship status as their basic right and how the Indonesian government makes efforts to protect them and their basic rights.

\section{Method}

This is legal research that combines two methods, namely juridical normative ${ }^{19}$ and socio-legal research aiming to see the implementation of the normative law to provide guarantees of justice for children to get their basic rights as citizens. It was conducted to find a solution to the problem of Indonesian migrant workers' children who were born and live in Malaysia and having no citizenship as well as access to their basic rights. The approach used is a qualitative one ${ }^{20}$ while primary legal sources come from Indonesian laws and regulations. Secondary sources, meanwhile, are from books, journal articles, in-depth interviews, and direct observations. All legal materials are arranged systematically before being processed and researched as well as evaluated and analyzed descriptivelyanalytically.

\section{Discussion and Result}

Indonesia and the Problem of Malaysian Migrant Workers

Data from the Indonesian Migrant Workers Protection Agency (BP2MI; Badan Pelindungan Pekerja Migran Indonesia) ${ }^{21}$ reveals that the number of Indonesian migrant workers in 2019 was 276,553 spreading in more than 26 countries in the world. It consists of 133,993 people working in the formal sector and 142,560 people working in the

19 Soejono Soekanto and Sri Mamudji, Penelitian Hukum Noermatif, Suatu Tinjauan Singkat (Jakarta: Raja Grafindo Perdana, 2001).

${ }^{20}$ A. M. D. Ali and H Yusof, '). Quality and Qualitative Studies: The Case of Validity, Reliability, and Generalizability. Issues in Social and Environmental Accounting', Journal ICSEARD, 5.1 (2011), 25-26.

${ }^{21}$ Republik Indonesia, Peraturan Presiden No. 90 Tahun 2019 Tentang Badan Pelindungan Pekerja Migran Indonesia, 2019. 
informal sector. 22 The number of migrant workers is directly proportional to the foreign exchange generated by the state from the remittances of its migrant workers. Bank Indonesia recorded the number of remittances from Indonesian migrant workers abroad in 2018 numbered USD 10,971 billion or equivalent to IDR 153.6 trillion. ${ }^{23}$ Of these, as much as USD 3,223 billion or $29.38 \%$ of remittances came from migrant workers in Malaysia.

Relating to this, the Indonesian government has set the minimum age limit to become an Indonesian migrant worker at least 18 years old ${ }^{24}$ which is also called a sexually active person. ${ }^{25}$ As a consequence, they typically have sexual urges, especially for those who previously had a spouse in Indonesia. ${ }^{26}$ This likely leads to a willingness to find a marriage partner although most of them choose unregistered marriages because the Malaysian government prohibits migrant workers from bringing their families along, getting married, and or giving birth in Malaysia considering that it is supposed to interfere with their working performance. ${ }^{27}$ Therefore, the ban of the Malaysian government certainly raises another bigger problem, namely children born in Malaysia to illegal migrant workers who will

22 Information Research and Development Center BNP2TKI, 2020 "Data Penempatan dan Perlindungan Pekerja Migran Indonesia Tahun 2019", Jakarta, page. 2

${ }^{23}$ Vinna Dinda Kemala and Enny Kusdarini, 'Legal Protection of Indonesian Migrant Workers (TKI) Overseas (Case Study of BP3TKI North Sumatera Province)', Fiat Justisia: Jurnal Ilmu Hukum, 14.1 (2020), 25.

${ }^{24}$ Law No. 18 of 2017, article 5 a.

${ }^{25}$ Number of PMI based on Marital Status: Married 110,393 people, Not Married 97,621 people and Divorced 68,539 people. See Data on the Placement and Protection of Indonesian Migrant Workers (PMI) for 2019, BNP2TKI page 2.

26 A total of $59.36 \%$ of Indonesian Migrant Workers in 2018 were single, and divorced, see Information Research and Development Center BNP2TKI, 2020 "Data on Placement and Protection of Indonesian Migrant Workers Year 2019", Jakarta, page. 3.

27 Interview with First Secretary of BNP2TKI Hermono on August 03, 2016 in accordance with Malaysian government regulations via Malaysian Immigration Act Number 1154A/2002. 
also become illegal children because they cannot have official citizenship documents.

\section{Access to Justice for Children of Migrant Workers}

Just is abstract that it needs appropriate operational definition to turn the concept into reality. ${ }^{28}$ Justice is equivalent to fairness as the main virtue in social institutions. ${ }^{29}$ Social justice here involves efficiency, coordination, and stability. Rawls further said that everyone has a right to justice that no one can interfere. Therefore, everyone should be treated equally. The right to justice, Rawls added, cannot be used as a political tool or a social interest. ${ }^{30}$ Rawls' statement clearly emphasizes how important access to justice for everyone is without any restrictions and conditions. Francesco Francioni, meanwhile, defines access for justice as a person's right to obtain legal protection and the availability of legal remedy mechanisms, both in the court and protection mechanisms quasijudicial equivalent. 31

Access to justice is therefore a fundamental right that is inseparable from the enforcement of human rights. It further becomes an important prerequisite for the protection and promotion of all other human rights. ${ }^{32}$ Meanwhile, access to justice for children is a specific right as well as the main pillar to fulfill human rights, promote good governance, and support sustainable development

${ }^{28}$ Bahder Johan Nasution, 'A Philosophical Study of the Concept of Justice from Classical Thought to Modern Thought', Journal of Yustisia, 3.2 (2014).

${ }^{29}$ John Rawls, A Theory of Justice (United State of America: Twentieth Printing, 1971), hlm. 3-4.

${ }^{30}$ Rawls.

31 Fransesco Francioni, 'Acces to Justice, Denial Of Justice and International Investment Law', The European Journal of International Law, 20.3 (2020).

32 United Nations General Assembly, Human Rights Councils, Access to Justice for Children, Annual report of the United Nations High Commissioner for Human Rights, and reports of the Office of the High Commissioner and the Secretary-General. 16 December 2013. 
programs. ${ }^{33}$ Children's human rights reflect their dignity as well as provide the legal guarantees because they can have their rights as long as the law protects them. ${ }^{34}$ Human rights are the basic needs of children and to protect it, it is necessary to strive for creating a situation that supports the right fulfillment while facilitating them to do their obligation in any place or nation they live..$^{35}$

Every child has the right to get protection and guidance from an early age. They also deserve equal opportunities to grow and develop optimally in physical, mental, and social. This particularly applies in their golden period so that in the next days, they are supposed to have the strength and ability to stand on their own. The previous generation should therefore guarantee, maintain and secure children ${ }^{36}$ as the next generation of a nation, particularly in guaranteeing their protection. ${ }^{37}$ Legal protection, additionally, is another part of children's human rights so that this obliges child protection to be regulated in relevant laws and regulations. ${ }^{38}$

Children's access to justice also requires legal empowerment. They should be enabled to access relevant information to claim their rights, including legal service, education, counseling or advice, and support from knowledgeable adults. In addition, access to justice for children requires consideration on the development of their maturity and understanding when exercising their rights. ${ }^{39}$

33 Julian Fleet, Permanent Observer to the United Nations in Geneva, In Anticipation of the 40th Session of the United Nations Human Rights Council in Geneva, 2019.

${ }^{34}$ Beni harmoni Harefa, Kapita Selekta Perlindungan Hukum Bagi Anak (Yogyakarta: Deepublish, 2012).

${ }^{35}$ Harefa.

36 Maidin Gultom, Perlindungan Hukum Terhadap Anak Dalam Sistem Peradilan Pidana Anak Di Indonesi (Bandung: Refika Aditama, 2008).

${ }^{77}$ Ratri Novita Erdianti and Sholahudin M. Fatih, 'Mewujudkan Desa Layak Anak Sebagai Nentuk Perlindungan Hukum Terhadap Anak Di Indonesia', Jurnal Justitia Junral Hukum, 3.2 (2019).

38 Harefa.

39 United Nations General Assembly, human Rights Counsil, Access to Justice for Children, Annual report of the United Nations High Commissioner for Human Rights and reports of the Office of the High Commissioner and the Secretary-General. 16 December 2013. 


\section{Children's Right to Citizenship}

As mandated by the constitution, every citizen deserves rights that the state needs to recognize, respect, protect, facilitate, and fulfill with all of its power and efforts. On the other hand, citizens as one of the most important elements of a country ${ }^{40}$ holding special position ${ }^{41}$ must recognize, respect, and obey the government or the state. 42 The relationship between the two is therefore reciprocal. ${ }^{43}$ This goes the same at the juridical relationship between individuals and the state in the sense of fulfilling each other's rights. ${ }^{44}$ Among others, the most basic right of citizens is the right to live and the right to get citizenship status. This is mainly because citizenship will lead to other rights that a person deserves to get. ${ }^{45}$

Indonesian laws and regulations have guaranteed the protection of children's rights, especially in obtaining self-identity and citizenship status.46 It reads: Every child has the right to a name as self-identity and citizenship status (Article 5 paragraph (1) and Article 27 paragraph (1) and (2) of Law No.23/2000). Meanwhile, Law Number 39 of 1999 concerning Human Rights in Article 53 consists of two following points: (1) Every child, since in the womb, has the right to live, maintain life, and improve his/her standard of living. (2)

${ }^{40}$ Law of the Republic of Indonesia Number 12 of 2006 concerning Citizenship of the Republic of Indonesia.

${ }^{41}$ Koerniatmanto Soetoprawiro, Hukum Kewarganegaraan dan Keimigrasian Indonesia, second edition (Jakarta: PT. Gramedia Pustaka Utama, 1996), hlm. 1.

42 Jimly Asshiddiqie, Pengantar Ilmu Hukum Tata Negara Jilid ll (Jakarta: Konsitusi Pers, 2006), hlm. 132.

43 Elucidation of Law Number 12 of 2006 concerning Citizenship of the Republic of Indonesia.

44 Shaila Tieken, 'Ketiadaan Kewarganegaraan Pada Anak-Anak Rohingya Sebagai Bentuk Kekerasan Struktural Berbasis Etnis: Studi Kasus Anak-Anak Pengungsi Rohingya Di Community Housing Wisma YPAP Medan', Jurnal Kriminologi Indonesia, 9.1 (2013).

45 Supriyadi A Arief, 'Unraveling Dual Citizenship in Indonesia in the Perspective of Human Rights and the Welfare State', Sasi Journal, 26.42020, 527-39.

${ }^{46}$ Yunanci Putri Sugeha, "Children's Right to Obtain Citizenship from Mixed Marriages," Jurnal Lex Et Societatis 26, no. 4 (2020), hlm. 527-39. 
Every child, from birth, has the right to a name and citizenship status. Likewise, at the broader scope, the Convention on the Rights of the Child approved by the United Nations General Assembly on November 20, 1989, Article 7, states: (1) The child will be registered immediately after his/her birth and since the birth has the right to a name, to acquire citizenship and as far as possible, to know and be cared for by his/her parents. (2) Fellow nations shall ensure the implementation of these rights under national law and their respective obligations under relevant international instruments in this field, particularly if the child becomes stateless. ${ }^{47}$

Therefore, it is clear that the state is obliged to fulfill and protect its citizens' rights, including the right of citizenship status. The status will make it easier for citizens to live their lives either in their original country or other countries. However, the problem arises because, in the context of Indonesia, the fulfillment of citizenship rights is quite rigid because according to Law Number 12 of 2006 concerning Citizenship of the Republic of Indonesia, it is disapproved to hold dual or bipartite citizenship. Bipartite is a condition of a person who has dual citizenship as a result of different nationalities.

\section{The Limited Access_for Children of Indonesian Migrant Workers in Sarawak Malaysia}

Referring to the research results of the Civil Society Consortium for the Access to Justice Index, portraying the limited access among illegal Indonesian migrant workers' stateless children can be seen from these following six types of measurement: 48

\section{The Root and Beginning of Unjust Access}

Indonesian migrant workers in Sarawak Malaysia are in trouble from various causes of a problem, mainly entering Malaysia through illegal procedures, having an expired residence and work permits, or

47 Directorate of Information System of Human RIght Republic Indonesia, 'Convention on The Right of The Child', p. 10.

${ }^{48}$ Hasril Ertanto, Access to Justice Index in Indonesia 2019 (Jakarta: Civil Society Consortium for Access to Justice Index, 2020). 
doing overstay. ${ }^{49}$ Another cause of the trouble is children born and living in the country. At Sarawak itself, there are approximately 20,000 children without citizenship status. 50 The number is likely showing an iceberg phenomenon while the real and original number is greater than the recorded one. The problem of justice for the children begins when they are about to go to school. They cannot study in any schools in Malaysia without official citizenship documents. Observations in the field show that there are at least two main things beyond this phenomenon, namely coming to Malaysia along with illegal migrant workers, who are their parents, and those who were born to Indonesians who got married to Malaysians but are not yet registered in Malaysia citizenship. ${ }^{51}$

\section{Legal Framework}

The United Nations issued the International Convention on the Rights of the Child in 1989 on the protection of children. This convention was later ratified by the Indonesian government through Presidential Decree No. 36 of 1990 as a law product in Indonesia that binds all Indonesian people. Furthermore, the Indonesian government confirmed Act No.23 of 2002 concerning Child Protection. Then, it was revised into Law No. 23 of 2002 with Law No. 35 of 2014 concerning child protection. The law is furthermore in line with the constitution, namely Article 28 B paragraph (2) of the 1945 Constitution which states that "every child has the right to survive, grow and develop as well as protection from any violence and discrimination". The mention of children's rights in the constitution shows that protection of children's rights is crucial, urgent, and mandatory that it needs regulation in technical legislation to ensure the children's right protection really works.

${ }^{49}$ Data on Overstayed Migrant Workers recorded is that in 2017 there were 237 people, in 2018 there were 42 people and in 2019 there were 805 . Health Center from the Placement and Protection of Indonesian Migrant Workers (PMI) in 2019, BNP2TKI page. 38.

50 Data CLC Se Sarawak diperoleh dari Nasrullah Ali Fauzi (Kordinator CLC se -Sarawak Malaysia).

${ }^{51}$ Disca Betty Viviansari and Zendy Wulan Ayu Widhi Prameswari, 'State Responsibility for the Right to Education of Indonesian Migrant Workers in Malaysia', Journal of Human Rights, Volume 10 (2019). 
Meanwhile, access for obtaining official birth certificates among the children of Indonesian migrant workers has actually been regulated. Among others, it is mentioned at The Law No. 23 of 2002, The Law No. 35 of 2014 concerning Child Protection, The Law No. 18 of 2017 concerning the Protection of Migrant Workers, The Law No. 6 of 2012 concerning Ratification of the International Convention on The Protection of The Rights of All Migrant Workers and Members of Their Families, The Law No. 37 of 1999 concerning Foreign Relations, The Law No. 23 of 2006 concerning Population Administration, and The Presidential Regulation No. 96 of 2018 concerning Requirements and Procedures for Population Registration and Civil Registration. Those legal frameworks have been relatively complete and theoretically able to provide protection for children. However, when it comes to practice, there are still found many obstacles because the legal enforcement requires the involvement of many institutions with respective roles as policymakers.

\section{Legal Dispute Resolution Mechanism}

Law No. 23 of 2002 and Law No. 35 of 2014 concerning Child Protection are the basis for children's protection. They cover the rules of criminal sanctions for those who violate the children's rights as well as mention those who are responsible for fulfilling the right, namely parents, family, government, and the state. In contrast to many other legal instruments that regulate human rights, the norms of the Child Protection Law oblige the state to do something (using the phrase "state is obliged to") instead of giving rights to individuals (using the phrase "everybody has a right to"). The first diction, according to the rules of statutory science, is considered stronger than the second one. ${ }^{52}$

However, practically, many Indonesian children in Malaysia do not have any birth certificates for various reasons. First, the registration fee at the National Registration Department (NRD) office is considered not cheap along with the complicated procedures. Second, the requirements are relatively difficult to fulfill, such as doing registration 42 days after the birthday at maximum. Third, procedures for making a late birth certificate are different in each office of NRD.

52 Yayan Sopyan. 
Fourth, children whose parents have lack official documents will find it difficult to complete the required documents. ${ }^{53}$

Knowing this situation, The Indonesian government has provided a legal breakthrough through the cooperation between the Ministry of Religious Affair, the Ministry of Foreign Affairs, and the Supreme Court in the Decision of the Chief Justice of the Supreme Court No. 084/KMA/SK/V/2011 concerning the permit for the Itsbat Nikah (formal marriage settlement) Trial at the Representative Office of the Republic of Indonesia at Malaysia. The documentation of Itsbat Nikah in Sarawak can be seen in Figure 1 below. The policy was then refined with the issuance of Supreme Court Regulation Number 1 of 2015 concerning Integrated Services for Circuit Courts of District Courts and Religious Courts/Sharia Courts in the Framework of Issuing Marriage Certificates, Marriage Books, and Birth Certificates. This integrated activity enables migrant workers to easily get two important documents, namely the Marriage Book and Birth Certificate so that children from such marriages can be protected for their basic rights such as having citizenship status and education. ${ }^{54}$ These two documents also enable them to register to the immigration office for obtaining a passport. 55

${ }^{53}$ Child Rights Coalition Malaysia. Status Report on Children"s Rights in Malaysia. Kuala Lumpur: Malaysian Child Resource Institute. 2012. page. 10.

54 https://www.antaranews.com/berita/774190/260-wni-di-kinabalumalaysia-ikuti-itsbat-nikah.

${ }^{55}$ Yusron Ambary, Head of the Consular Function of the Indonesian Embassy in Kuala Lumpur, Head of the Consular Function of the Indonesian Embassy in Kuala Lumpur, 2020. 
Figure 1.

The situation of the itsbat trial at The Sarawak Consul General's Office.

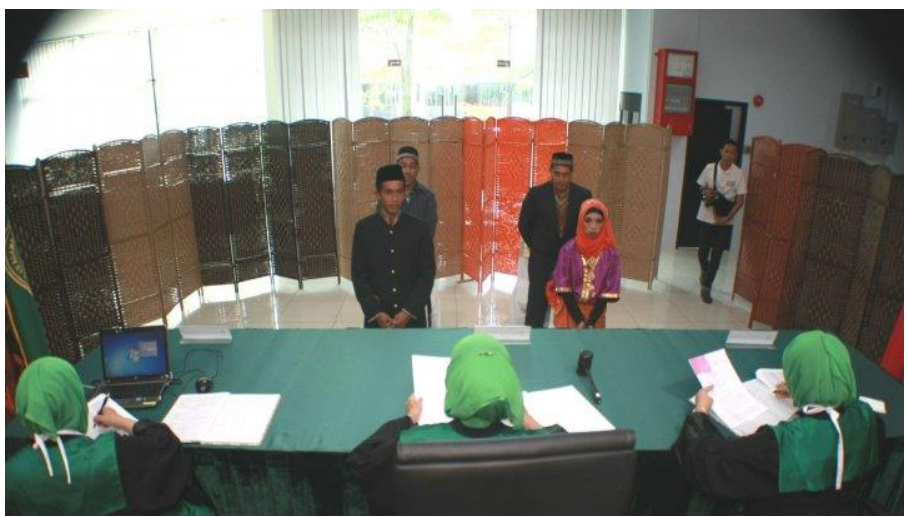

Source: Tribunnews.com

Due to the implementation of this policy, there carried out itsbat trial as many as 144 cases in $2012 .{ }^{56}$ It then found 110 couples at $2013^{57}$ and 107 couples at $2016^{58}$ of 191 who registered but due to several obstacles, they could not attend the trial. In 2017, it increased to 255 couples. $^{59}$ Two years after, at 2019, there launched Marriage Information Management System (SIMKAH; Sistem Manajemen Informasi Nikah) aiming to make it easier for migrant workers to get the service. SIMKAH is planned to get integrated with the WNI care

${ }_{56}$ Mahkamah Agung, Annual Report of Central Religious Court Central Jakarta, 2012.

57

https://regional.kompas.com/read/2016/09/27/06070031/kisah.tki.yang.b aru.

mempunyai.buku.nikah.setelah.30.tahun.menikah?page=all 58

https://regional.kompas.com/read/2016/07/19/23502661/september.100. pasang.wni.akan.jalani.itsbat.nikah.di.sarawak.malaysia?page $=$ all.

59 Annual report of the Central Jakarta Religious Court, page 23. The details are that 221 cases were granted, 1 case was rejected and 33 cases were aborted. 
portal so that it can then be used by all Indonesian Representatives abroad. 60

Beyond all the system and procedure, it still finds various obstacles when it comes into practice, mainly at the problem of distance and travel cost, one of them happened in Khucing City. The situation after Istbat Nikah in Khucing can be seen in Figure 2 below.

\section{Figure 2.}

The Situation After Itsbat Ceremony in Khucing

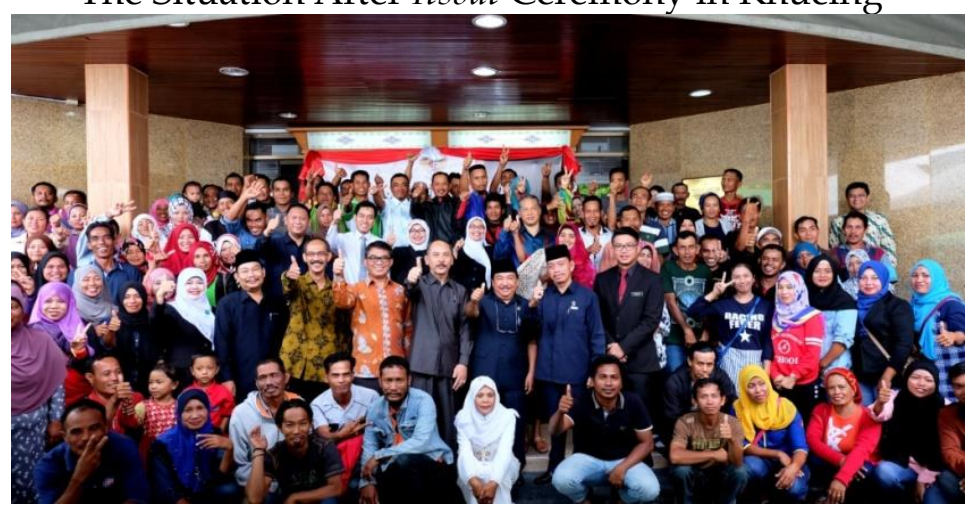

Source: The documentation of the Consul General of the Republic of Indonesia in Kuching

The distance between the Indonesian Consul General's Office in Kuching City, the location of the marriage settlement trial, and the residences of Indonesian migrant workers are relatively far away. Most of them live in the area of Bintulu, Galasah, to Miri next to Brunei Darussalam border. To reach the destination in Kuching city, Indonesian migrant workers in Miri, for example, take about 12 hours by bus and have to travel as far as $+650 \mathrm{Km}$ with a bus ticket cost of RM. 90 to RM. 140 or around IDR 350.000,- up to IDR 500,000,-61

\section{Legal Aid}

The issue of stateless children in Malaysia has been around for a long time and is still becoming a serious problem for the Malaysian government. The Malaysian Home Affairs Minister, Muhyiddin

60 `41 Pasangan WNI Ikuti Sidang Isbat Nikah Di Wisma Indonesia KJRI Johor Bahru’.

61 data obtained from direct observations and in-depth interviews with Nasrullah Ali Fauzi, an Indonesian volunteer for education. 
Yassin, said that he would pay very much and serious attention while speeding up the process of managing citizenship registration. Additionally, Suruhanjaya Hak Asasi Manusia Malaysia (SUHAKAM), together with the same Indonesian-level institution, Komnas HAM (National Commission for Human Rights), and the Commission on Human Rights (CHR) of the Philippines have signed a memorandum of understanding to try to solve the problem of stateless children. ${ }^{62}$

The memorandum becomes important basically because the fulfillment of citizens' rights is the responsibility of the origin country. When they live in another country, however, they will certainly need assistance from the country they live in. The Indonesian representative in Sarawak Malaysia has made various efforts to reach out to migrant workers in the palm oil fields. Among the efforts is disseminating relevant information to Indonesian migrant workers. This aims to reduce the costs that the migrant workers need to pay in the processing administration of civil registration.

The problem of distance and time also matters. Indonesian migrant workers in Sarawak plantation usually pay for services to a fellow worker who helps the administration process, including travel documents, birth certificates, and other citizenship documents, by visiting Indonesian representatives in Kuching. This fellow typically waits for several people who use his/her service before making one single visit to reduce travel costs. ${ }^{63}$

\section{Birth Certificate Process}

In general, issuing birth certificates for children of Indonesian migrant workers born in Sarawak, Malaysia, requires birth authentic evidence so that the competent authority can issue a birth certificate. ${ }^{64}$ This is the enforcement from the rule mentioning that birth registration for Indonesian citizens living outside the territory is carried out by the Representative of the Republic of Indonesia in the country where the child was born by fulfilling the following

62 'Keturunan WNI Tanpa Kewarganegaraan: "Saya dipukul oleh Bapak, Lari Dan Merantau Ke Malaysia" - BBC News Indonesia'.

63 'Pelayanan Jemput Bola KJRI Kuching Di Bintulu, Sarawak'.

${ }^{64}$ Victor M. Situmorang dan Cormentyna Sitanggang, Aspects of Civil Registry Law in Indonesia (Jakarta: Sinar Grafika, 2006), hlm.41. 
requirements: 1) Quotation of the child's birth certificate from the local country. 2) Indonesian travel document of the parents. 65 However, in the context of Serawak or Malaysia, the process needs the following requirements: (1). Application letter from parents. Every parent who will apply for a birth certificate for their child must apply to the Indonesian Representative. (2) Passport of the Republic of Indonesia or Letter of Agreement as Passport (SPLP; Surat Perjanjian Laksana Pasport), working visa, \& a valid stay permit of the parents. (3) Indonesian identity card/Malaysian identification card (KP/IC) of the parents. (4) Marriage certificate of the parents. (5) Birth certificate of the parents. (6) 2 (two) passport-sized photographs of the child (7) Administration fee of RM 103.00 (Malaysian Ringgit One Hundred Three) paid to the Consulate General of the Republic of Indonesia at Kuching after all documents and letters are verified correct and complete. Payment can be made in cash or transferred to a predetermined account. (8) Photocopy of Malaysian Passport/Kd Identification (KP/IC) of 2 (two) witnesses. A copy of the passport and Identity Card of the two is also required if the child is not born at the hospital.

When the documents are complete, their copy needs to be delivered to the authorized official of the Indonesian Representative in Kuching, Malaysia. A special officer who handles the issuance of birth certificates will continue the process. If all of the requirements have been met, the birth certificate can be awaited and immediately available on the same day.

However, a serious problem usually occurs when the migrant workers have no stay permit or get their passport lost, taken by the cukong, stuck in the old workplace, or expired. They will likely be afraid to deal with the police or the Indonesian Consul General for getting help to meet all requirements so that the children of those illegal migrant workers are unable or difficult to complete the above requirements and obtain their citizenship identity.

65 President of Republic Indonesia, Article 24 of the Law on Foreign Relations (Indonesia, 2018). 
Yayan Sopyan

\section{Community Capability}

Indonesian migrant workers in Sarawak Malaysia typically have just been aware of the issue of children's birth registration when the child is about go to school. This is because Malaysian government prohibits migrant workers' children without official documents to attend Malaysian schools. What makes it difficult in the process of making birth certificates for migrant workers is due to parental documents, distance, time, and cost, plus the weak knowledge of migrant workers about the importance of birth certificates.

This negligence becomes worse by the absence or lack of education about this issue among the migrant workers. Therefore, the government should be more progressive to provide education about the issue as well as facilitate them to obtain legal documents by engaging several relevant institutions. It also needs to consider for creating a system with an easy and quick process without requiring the workers to spend a lot of money to obtain official documents needed.

\section{Conclusion}

As an obligation, the Indonesian government has made various efforts to protect the children of illegal migrant workers in Sarawak in obtaining their basic right namely citizenship status. However, this effort has not been effective due to several obstacles as follows: First, illegal migrant workers in Sarawak have existed for three generations. Second, they spread over a very wide area and were not recorded because they came illegally. Third, the number of children who do not have citizenship is very large. Fourth obstacle is the lack of strict supervision from both the Indonesian and the Malaysian governments about the entrance of Indonesian workers. Fifth, what has been done by the government in recent years is still on a very small scale that it has not been able to reach all Indonesian children in Sarawak. Sixth, the education level of migrant workers is relatively low and they do not realize the importance of citizenship, especially for their children. Seventh, there is still weak socialization from the government about the importance of having a state identity for migrant workers. Therefore, this condition obliges continual controlling, evaluation, and improvement from the community and the government, particularly KPAI (Komisi Perlindungan Anak Indonesia; Indonesian Commission for Child Protection). 


\section{Bibliography}

https://kemlu.go.id/johorbahru/id/news/3834/41-pasanganwni-ikuti-sidang-isbat-nikah-di-wisma-indonesia-kjrijohor-bahru 41 Pasangan WNI Ikuti Sidang Isbat Nikah di Wisma Indonesia KJRI Johor Bahru." Diakses 20 Desember 2021.'41 Pasangan WNI Ikuti Sidang Isbat Nikah Di Wisma Indonesia KJRI Johor Bahru'

Ali, A. M. D., and H Yusof, '). Quality and Qualitative Studies: The Case of Validity, Reliability, and Generalizability. Issues in Social and Environmental Accounting', Journal ICSEARD, 5.1 (2011), 25-26

Allerton, Catherine, Statelessness and the Lives of the Children of Migrants in Sabah (Malaysia, 2014)

Allerton, Cetherine, 'Statelessness and the Lives of the Children of Migrants in Sabah, East Malaysia.', Tilburg Law Review: Journal of International and European Law, 19.1-2 (2014), 2634

Ambary, Yusron, Head of the Consular Function of the Indonesian Embassy in Kuala Lumpur, Head of the Consular Function of the Indonesian Embassy in Kuala Lumpur, 2020

Arief, Supriyadi A, 'Unraveling Dual Citizenship in Indonesia in the Perspective of Human Rights and the Welfare State', Sasi Journal, 26.42020, 527-39

Asshiddiqie, Jimly, Pengantar Ilmu Hukum Tata Negara Jilid Ll (Jakarta: Konsitusi Pers, 2006)

BNP2TKI, Data on Placement and Protection of Indonesian Migrant Workers, 2020

Directorate of Information System of Human RIght Republic Indonesia, 'Convention on The Right of The Child', p. 10

Disca Betty Viviansari and Zendy Wulan Ayu Widhi Prameswari, 'State Responsibility for the Right to Education of Indonesian Migrant Workers in Malaysia', Journal of Human Rights, Volume 10 (2019) 
Eddyono, Sri Wiyanti, Research Report: The Profile of Trafficking in Persons in The Border Area of Kalimantan, Studies of The Districts of Sanggau, Sambas, Kapuas Hulu and Nunukan, ed. by Counter-Trafficking Unit IOM Indonesia (Jakarta: International Organization for Migration (IOM) Indonesia, 2020)

Erdianti, Ratri Novita, and Sholahudin M. Fatih, 'Mewujudkan Desa Layak Anak Sebagai Nentuk Perlindungan Hukum Terhadap Anak Di Indonesia', Jurnal Justitia Junral Hukum, 3.2 (2019)

Ertanto, Hasril, Access to Justice Index in Indonesia 2019 (Jakarta: Civil Society Consortium for Access to Justice Index, 2020)

Faizin, Alfan, Alfitra, and Ali Mansur, 'Legalizing Unofficial Marriage For Indonesian Migrant Workers In Malaysia', Jurnal Cita Hukum, 7.1 (2020)

Fleet, Julian, Permanent Observer to the United Nations in Geneva, In Anticipation of the 40th Session of the United Nations Human Rights Council in Geneva, 2019

Francioni, Fransesco, 'Acces to Justice, Denial Of Justice and International Investment Law', The European Journal of International Law, 20.3 (2020)

Gultom, Maidin, Perlindungan Hukum Terhadap Anak Dalam Sistem Peradilan Pidana Anak Di Indonesi (Bandung: Refika Aditama, 2008)

Harefa, Beni harmoni, Kapita Selekta Perlindungan Hukum Bagi Anak (Yogyakarta: Deepublish, 2012)

Harkons, Benjamin, and Meri Ahlberg, Access to Justice for Migrant Worker Ins South-East Asia (Bangkok: ILO, 2017)

Hidayat, 'Protection of Indonesian Workers Rights in Taiwan And Malaysia in Human Rights Perspective', Jurnal HAM, 8.2 (2017), 106

Kemala, Vinna Dinda, and Enny Kusdarini, 'Legal Protection of Indonesian Migrant Workers (TKI) Overseas (Case Study of BP3TKI North Sumatera Province)', Fiat Justisia: Jurnal 
Ilmu Hukum, 14.1 (2020), 25

‘Keturunan WNI Tanpa Kewarganegaraan: “Saya Dipukul Oleh Bapak, Lari Dan Merantau Ke Malaysia" - BBC News Indonesia'

Mahkamah Agung, Annual Report of Central Religious Court Central Jakarta, 2012

Massey, Douglas S., Joaquin Arango, Graeme Hugo, Ali Kouaoci, Adela Pellegrino, and J. Edward Taylor, Theories of International Migration: A Review and Appraisal. Population and Development Review, 1993

Nasution, Bahder Johan, 'A Philosophical Study of the Concept of Justice from Classical Thought to Modern Thought', Journal of Yustisia, 3.2 (2014)

'Pelayanan Jemput Bola KJRI Kuching Di Bintulu, Sarawak'

Prasetyo, Dimas Teguh, Tarma, and Vera Utami Gede Putri, ', Aku Masih Cinta Indonesia: Study of Nationalism in Family Character Education on Children of Indonesian Migrant Workers in Malaysia', Journal of Family Welfare and Education, 7.1 (2020)

President of Republic Indonesia, Article 24 of the Law on Foreign Relations (Indonesia, 2018)

Rawls, John, A Theory of Justice (United State of America: Twentieth Printing, 1971)

Republik Indonesia, Naskah Akademik RUU Tentang Pengesahan Asean Convention Againts Trafficking in Persons, Especially Women and Children (Konvensi Asean Menentang Perdagangan Orang Terutama Perempuan Dan Anak-Anak (Jakarta: Kementerian Hukum dan Hak Asasi Manusia, 2016)

- - -, Peraturan Presiden No. 90 Tahun 2019 Tentang Badan Pelindungan Pekerja Migran Indonesia, 2019

Situmorang, Victor M., and Cormentyna Sitanggang, Aspects of Civil Registry Law in Indonesia (Jakarta: Sinar Grafika, 2006)

Soekanto, Soejono, and Sri Mamudji, Penelitian Hukum Noermatif, Suatu Tinjauan Singkat (Jakarta: Raja Grafindo 
Perdana, 2001)

Soetoprawiro, Koerniatmanto, Hukum Kewarganegaraan Dan Keimigrasian Indonesia, Second Edition (Jakarta: PT. Gramedia Pustaka Utama, 1996)

Sugeha, Yunanci Putri, 'Children's Right to Obtain Citizenship from Mixed Marriages', Jurnal Lex Et Societatis, 26.4 (2020), 527-39

Sutianto, Feby Dwi, 400.000 WNI Di Sarawak, Legal Atau Ilegal?, 2018

Tieken, Shaila, 'Ketiadaan Kewarganegaraan Pada Anak-Anak Rohingya Sebagai Bentuk Kekerasan Struktural Berbasis Etnis: Studi Kasus Anak-Anak Pengungsi Rohingya Di Community Housing Wisma YPAP Medan', Jurnal Kriminologi Indonesia, 9.1 (2013)

Viviansari, Disca Betty, and Zendy Wulan Ayu Widhi Prameswari, 'State Responsibilities of Rights to Education for Indonesian Migrant Worker's Children in Malaysia', Jurnal HAM, 10.2 (2019), 182

Wahyudi, Ridwan, 'Illegal Journey: The Indonesian Undocumented Migrant Workers to Malaysia.', Populasi, 25.2 (2017), 24

Yayan Sopyan, 'The Access to Justice for Indonesian Migrant Workers (In Malaysia, Saudi Arabia and Hongkong)', International Journal of Advanced Science and Technology, 29 No (2020), 95-108 